Article

\title{
Determination of Insecticide Susceptibility of Field Populations of Tomato Leaf Miner (Tuta absoluta) in Northern Nigeria
}

\author{
Ibrahim Bala ${ }^{1,2}$, Muhammad M. Mukhtar ${ }^{1}$, Habeeb K. Saka ${ }^{2} \mathbb{D}$, Nasiru Abdullahi ${ }^{1}$ and \\ Sulaiman S. Ibrahim 1,3,*(D) \\ 1 Department of Biochemistry, Bayero University, PMB 3011 Kano, Nigeria; binbala04@gmail.com (I.B.); \\ muhammadmahemukhtar@gmail.com (M.M.M.); nabdullahi.bch@buk.edu.ng (N.A.) \\ 2 Nigerian Stored Products Research Institute, Kano Office, PMB 3032 Kano, Nigeria; saka.habeeb@yahoo.com \\ 3 Vector Biology Department, Liverpool School of Tropical Medicine, Liverpool L3 5QA, UK \\ * Correspondence: sulaimansadi.ibrahim@1stmed.ac.uk; Tel.: +234-80-2901-0371
}

Received: 2 December 2018; Accepted: 25 December 2018; Published: 1 January 2019

check for updates

\begin{abstract}
In 2016, northern Nigeria experienced a devastating infestation by the tomato leaf miner, leading to soaring in prices of tomatoes across the country. Unfortunately, information on the resistance status of this pest is lacking in northern Nigeria, hampering appropriate control measures. Here, we identified to species level and, using bioassays, characterised insecticide susceptibility profile of a field population of a tomato leaf miner from northern Nigeria. Highest resistance was observed with $\lambda$-cyhalothrin (a Type II pyrethroid) with a low mortality $(18.52 \%$ at $56 \mathrm{~h}$ ) and $\mathrm{LD}_{50}$ of $7461.474 \mathrm{ppm}$. Resistance was also established toward propoxur and chlorpyrifos-methyl with average mortalities each of $56 \%$ and LD $_{50 \mathrm{~s}}$ of $1023.51 \mathrm{ppm}$ and $106.351 \mathrm{ppm}$, respectively. Highest susceptibility was observed from abamectin with mortality of $86 \%$ and $L_{50}$ of $0.034 \mathrm{ppm}$. Pre-exposure to the synergist piperonylbutoxide significantly recovered $\lambda$-cyhalothrin susceptibility ((mortality 90\%, $\left.\chi^{2}=98.35, p<0.0001\right)$ and $\left.\mathrm{LD}_{50}=0.92 \mathrm{ppm}\right)$ implicating P450 monoxygenases. No significant changes were observed on pre-exposure to diethyl maleate and triphenylphosphate-inhibitors of glutathione S-transferases and carboxylesterases, respectively. Sequencing of domain II of the voltage-gated sodium channel established 1014F $k d r$ mutation $100 \%$ fixed in both $\lambda$-cyhalothrin-alive and dead larvae. These findings highlight the challenges for control of this invasive agricultural pest in northern Nigeria.
\end{abstract}

Keywords: Savanna; Nigeria; tomatoes; Tuta absoluta; metabolic; resistance; $k d r$

\section{Introduction}

The leaf miner, Tuta absoluta (Meyrick 1917) (Lepidoptera: Gelechiidae), native to South/Central America [1], is one of the most devastating pests of tomato (Solanum lycopersicum L.), potato (Solanum tuberosum L.) and other solanaceous plants [2]. Since its first appearance in Spain in 2006 [3] T. absoluta has expanded its geographic range outside Americas [4], and is now found in far flung places in Europe [5,6], middle East/Asia [7,8] and Africa [9,10]. Following its first appearance in sub-Saharan Africa at Senegal [11], this pest has expanded southward and, in recent years, has been reported in East [12] and southern African countries [13]. Africa is a continent where the agricultural sector accounts for more than $60 \%$ of total labour force [14], and Nigeria is the largest producer of tomato in the continent [15]. However, following the 2016 T. absoluta invasion (nicknamed 'tomato ebola') more than $80 \%$ of the tomato produce was lost in northern Nigeria [16], leading to estimated 10-fold increase in tomato prices [17]. In Kano State alone, farmers lost more than 2 billion Nigerian Naira in the 2016 season [18]. 
Farmers from northern Nigeria responded by increasing the quantities of pesticides they apply (personal communication), often in mixtures of classes having similar mode of actions. At Kadawa farms in Kano, where collection for this study was conducted, farmers were found to be using the following pesticides for control of the leaf miner: (i) Expert 50 WDG, Emacot 050 WG, and Caterpillar Force, all three made of Emamectin benzoate; and (ii) TEMA, made of emamectin benzoate $(60 \mathrm{~g} / \mathrm{kg})$ and Teflubenzurone $(75 / \mathrm{kg})$. They claimed that TEMA is the most effective of all four formulations.

Unfortunately, scientific evidence on pesticide resistance profile and its underlying molecular mechanisms in T. absoluta was non-existent in Nigeria prior to this study. Elsewhere, significant progress has been reported on the bionomics of this pest, its pesticides resistance status, and the underlying molecular mechanisms driving the resistance in the field. Studies in different countries have shown that T. absoluta has developed resistance to insecticide classes in use for its control $[19,20]$. Cases of resistance in T. absoluta and its underlying molecular mechanisms have been reported in Southern America and Europe, e.g. in Chile and Brazil [21,22], and are reported in Greece, Italy, Spain, and Portugal $[23,24]$. In Africa, reliable studies that describe pesticide resistance in this pest are from Ethiopia, e.g. the recent work by Ayalew and Shiberu, with their colleagues $[25,26]$.

Since insecticide resistance could be heterogenous even over short distances, as observed in other species like mosquitoes [27], it is not wise to extrapolate findings from other countries to the local populations in Nigeria and/or Africa. To fill these gaps in knowledge and provide information to the relevant agricultural authorities, we characterised a field population of T. absoluta from a single site in the Sudan Savanna of northern Nigeria. Following field collection and morphological identification, subsample of the T. absoluta were identified to species level using molecular approach. Insecticides resistance profile was then established and the possible enzymes systems responsible for metabolic resistance interrogated using synergist bioassays. The T. absoluta populations were resistant to pyrethroid, carbamate, and organophosphate insecticides, with resistance also suspected to abamectin. Synergist bioassays significantly recovered susceptibility with mortalities increasing fourfold on average; revealing that the P450 monooxygenases are possibly involved in the pyrethroid resistance. Sequencing of the domain II, transmembrane helix 6 fragment of the voltage-gated sodium channel encompassing the 1014 codon identified the presence of the $1014 \mathrm{~F} k d r$ mutation in all larvae alive and dead from exposure to $\lambda$-cyhalothrin.

\section{Materials and Methods}

\subsection{Materials}

Chemicals and Reagents

The four different insecticides classes used for the bioassays: $\lambda$-cyhalothrin (a type II pyrethroid with an $\alpha$-cyano group, IRAC Class 3A), propoxur (a carbamate, IRAC Class 1A), chlorpyrifos-methyl (an organophosphate, IRAC Class 1B) and abamectin (an ivermectin, IRAC Class 6), were purchased from SIGMA ALDRICH, UK (Dorset, United Kingdom). The triton X-100 and the synergists piperonyl butoxide (PBO) and diethyl maleate (DEM) and triphenyl phosphate (TPP) were all purchased from SIGMA, Dorset, UK. For species identification, the KAPATaq kit (https://www.kapabiosystems.com/) was used to amplify the cytochrome oxidase fragment, and for amplification of IIS6 domain of the voltage-gated sodium channel QuantaBio HiFi Accustar II SuperMix (www.quantabio.com) was used. Other chemicals used were to make a LIVAK DNA extraction buffer and are given in the methods section. 


\subsection{Methods}

\subsubsection{Field Collection and Rearing of Insects}

T. absoluta larvae and eggs at different stages of development were collected from tomato farms at Kadawa ((11.6457 $\left.{ }^{\circ} \mathrm{N}, 8.4479^{\circ} \mathrm{E}\right)$, Figure 1) in Garun Mallam Local Government Area, Kano, Nigeria. Collection was done for two days in three farms in April 2017.

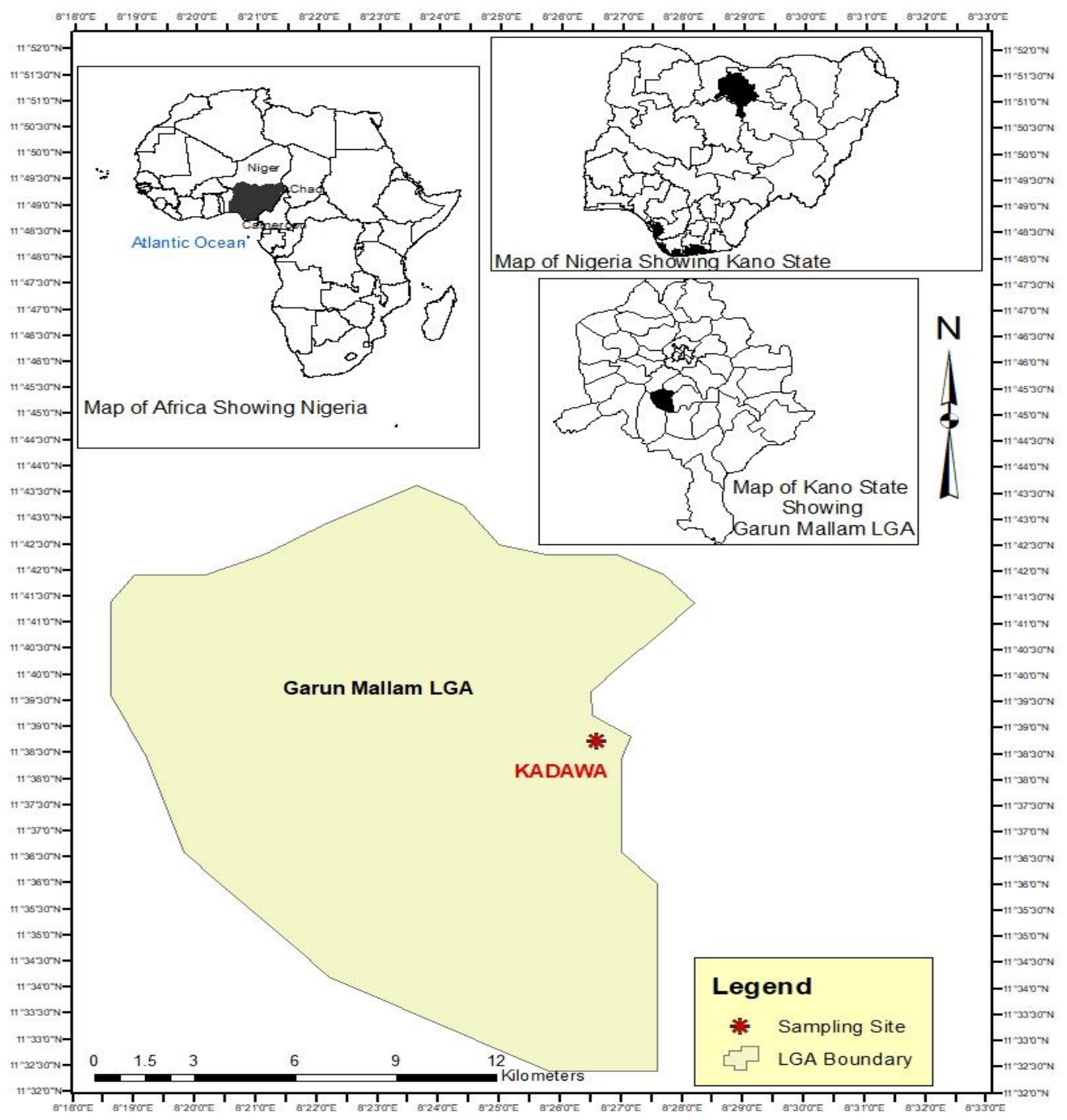

Figure 1. Sampling site, showing the location of Kadawa, Kano State, Nigeria.

Eggs and larvae were placed into large, wet jute bags. Approximately 300 larvae were collected. The samples were transferred to net cages measuring $70 \mathrm{~cm} \times 50 \mathrm{~cm} \times 50 \mathrm{~cm}$ (height $\times$ width $\times$ depth), locally constructed following established procedure [28]. This was done within an hour of collection to avoid stressing the larvae. Cages were maintained at $22-25{ }^{\circ} \mathrm{C}$, relative humidity of $70-75 \%$, and a photoperiod of 12:12 h (light:dark cycle) at Wellcome-Bayero Insectary, at Bayero University Kano, Nigeria. Adults that emerged were provided daily with fresh tomato leaves and allowed to mate. After laying eggs, the $\mathrm{F}_{0}$ parents were transferred into other cages and killed. Sixteen (16) randomly selected adults were selected for morphological identification and molecular identification. Fresh foliage was provided daily for the newly emerged $F_{1}$ larvae and allowed to grow for 3-5 more days until the second instar stage (after second moulting). The tomato leaves were continually sprayed with water to keep them from wilting. 


\subsubsection{Morphological Identification of T. absoluta Life Stages}

Identification of eggs, larvae, pupae, and the field-collected adults was carried out morphologically using a stereomicroscope and following the protocol of European and Mediterranean Plant Protection Organisation (EPPO) [2].

\subsubsection{Molecular Identification of T. absoluta to Species Level}

Following morphological identification $16 \mathrm{~F}_{0}$ parents were used for DNA extraction using previously established protocol [29]. Buffer was made by dissolving $5.48 \mathrm{~g}$ sucrose, $1.57 \mathrm{~g}$ Tris, $1.6 \mathrm{~mL}$ of $5 \mathrm{M}$ sodium chloride in $10.16 \mathrm{~mL}$ of $0.5 \mathrm{M}$ EDTA. This was then followed by a $2.5 \mathrm{~mL}$ of $20 \%$ SDS, and the volume was finally made up to $100 \mathrm{~mL}$ in a volumetric flask. The buffer solution was then filtered and sterilised. Then, $5 \mathrm{~mL}$ aliquots were stored at $-20{ }^{\circ} \mathrm{C}$, which was heated in a water bath and whirled to re-dissolve precipitate before use. Larvae were homogenized individually using a battery-operated mortar and pestle (SIGMA) in $50 \mu \mathrm{L}$ preheated grind buffer in $1.5 \mathrm{~mL}$ Eppendorf. The pestle was rinsed with a further $50 \mu \mathrm{L}$ of the buffer to a total of $100 \mu \mathrm{L}$. Homogenate was incubated at $65{ }^{\circ} \mathrm{C}$ for $30 \mathrm{~min}$. Condensation was collected by microfuging and $14 \mu \mathrm{L}$ of $8 \mathrm{M}$ of potassium acetate added to a final concentration of $1 \mathrm{M}$. Samples were vortexed and incubated for $30 \mathrm{~min}$ on ice. Tubes were centrifuged at $13,000 \mathrm{rpm}$ for $20 \mathrm{~min}$, at $4{ }^{\circ} \mathrm{C}$, after which the supernatant was transferred carefully to a $1.5 \mathrm{~mL}$ Eppendorf. At this point, $200 \mu \mathrm{L}$ of $100 \%$ ethanol was added and mixture centrifuged again at $13,000 \mathrm{rpm}$ for $15 \mathrm{~min}$, at $4{ }^{\circ} \mathrm{C}$. Pellets was rinsed in approximately $100 \mu \mathrm{L}$ ice cold $70 \%$ ethanol, air-dried for $1 \mathrm{hr}$ and then re-suspended in $100 \mu \mathrm{L}$ of distilled water. Tubes were finally incubated at $65^{\circ} \mathrm{C}$ for $10 \mathrm{~min}$.

Identification to species level was carried out by amplifying Cytochrome Oxidase subunit I (COI) gene using polymerase chain reaction [30,31]. The universal forward and reverse primers: LCO1490 (5'-GGTCAACAAATCATAAAGATATTGG-3' and HCO2198 (5'-TAAACTTCAGGGTGA CCAAAAAATCA-3') were used for PCR using $1 \mu \mathrm{L}$ each of the genomic DNA in a total reaction volume of $15 \mu \mathrm{L}$. Reaction mix comprise $1.5 \mu \mathrm{L}$ of $10 \times$ TaqA Buffer, $\sim 0.4 \mu \mathrm{M}(0.5 \mu \mathrm{L})$ of each of forward and reverse primers, $1.25 \mathrm{mM}(0.75 \mu \mathrm{L})$ of $\mathrm{MgCl}_{2}, 0.25 \mathrm{mM}(0.15 \mu \mathrm{L})$ of dNTP mixes and $0.12 \mu \mathrm{L}$ of Taq DNA polymerase, in $\mathrm{ddH}_{2} \mathrm{O}$. Amplification was carried out using the following conditions: initial denaturation of $5 \mathrm{~min}$ at $95^{\circ} \mathrm{C}$, followed by 35 cycles each of $30 \mathrm{~s}$ at $94{ }^{\circ} \mathrm{C}$ (denaturation), $30 \mathrm{~s}$ at $57{ }^{\circ} \mathrm{C}$ (primer annealing) and $1 \mathrm{~min}$ at $72{ }^{\circ} \mathrm{C}$ (extension). This was followed with $10 \mathrm{~min}$ final extension at $72{ }^{\circ} \mathrm{C}$. PCR products were separated in a $1.5 \%$ agarose gel stained with ethidium bromide. Eight (PCR) products were cleaned with a QIAquick ${ }^{\circledR}$ PCR Purification Kit (QIAGEN, Hilden, Germany) and sequenced on both strands. Sequences were assembled and edited using the BioEdit 7.2.3.0 [32] and the CLC sequence viewer 6.9 (http:/ / www.clcbio.com/). Consensus sequences were BLASTED (NCBI Blastn) in the GenBank database (http:/ / www.ncbi.nlm.nih.gov/) for identification and comparison with sequences previously deposited. Sequences were deposited at the GenBank with accession numbers MK189155- MK189162.

\subsubsection{Insecticides (Leaf-Dip) Bioassay}

Initial bioassay was conducted to establish the susceptibility profile of the T. absoluta larvae to the four different insecticides classes in use for control of agricultural pests. In total, 270 L2 larvae were utilized, 234 for tests with pesticides and 36 for control. Larvae were sorted using a fine brush according to sizes to select those at the second instar stage. Insecticides were tested using the leaf-dip bioassay protocol of the Insecticide Resistance Action Committee (IRAC test method \# 022) [33] with modifications. However, due to high mortality before standardization of insectary conditions low numbers of larvae were used in these bioassays compared with the recommendation of Insecticide Resistance Action Committee. Initially, acetone stock solutions at different concentrations were prepared for the various insecticides: $0.1 \%$ abamectin, and $0.5 \%$ each of propoxur, chlorpyrifos-methyl and $\lambda$-cyhalothrin. These were serially diluted into decreasing concentrations (1:6) in water containing 
$0.01 \%$ Triton X-100. Fresh tomato leaves were cut to equal sizes of $2.5 \mathrm{~cm}$ diameter using hand-held punch. For each insecticide, for the 6sixdifferent concentrations, nine tomato leaves (three replicates of three leaves) were dipped individually into insecticide solution, with gentle agitation. The only exception was abamectin with eight different concentrations instead of six. After treatment, the leaves were placed individually on wire net for $60 \mathrm{~s}$ to dry. Individual leaves were transferred into bioassay trays (ref: RT32W) containing slightly moistened filter paper. A fine soft brush was used to transfer the second instar larvae (three replicates of three larvae) into cells in the bioassay trays, individually and the trays covered with a lid (ref: RTCV4). Trays were closed carefully, sealing the cells with their lids and then stored at about $25 \pm 2{ }^{\circ} \mathrm{C}, 60-70 \%$ relative humidity, and 12:12 h light: dark photoperiod. Leaf damage as well as larvae mortality were then evaluated after $56 \mathrm{~h}$. Larval mortality was recorded with regards to those which were unable to make coordinated movement from gentle stimulus with fine pointed forceps to the posterior body segment (considered dead or seriously affected by the insecticide). To establish antifeeding effect leaf damage was evaluated by physical examination of the leaves. Since uniform leaves $(\sim 2.5 \mathrm{~cm}$ punched out) at the beginning of the assay the extent of damage was estimated as percentage of total leaf area mined (IRAC method \# 022). For control, the same procedure as above was followed with nine larvae sets for each experiment with the different insecticides, excepting that the leaves were dipped into water containing acetone.

\subsubsection{Synergists Bioassay}

To determine the possible contribution of metabolic resistance in the T. absoluta populations, synergist assay was conducted with piperonyl butoxide (PBO: an inhibitor of P450 monooxygenases), DEM (an inhibitor of glutathione S-transferases) and TPP (an inhibitor of esterases) against $\lambda$-cyhalothrin (the insecticide to which the larvae exhibited the highest resistance). 108 L2 larvae were used for the synergist test and 27 for control. Three replicates of three larvae per insecticide concentration were placed in cell units containing a leaf dipped into either $4 \% \mathrm{PBO}, 8 \% \mathrm{DEM}$ or $10 \%$ TPP (all synergists prepared in acetone) for $1 \mathrm{hr}$, as done in some other insects [34,35]. The larvae were then immediately transferred into bioassay cells containing leaves individually dipped into the various concentrations ( $0.643 \mathrm{ppm}, 3.853 \mathrm{ppm}, 23.15 \mathrm{ppm}$, and $138.89 \mathrm{ppm}$ ) of $\lambda$-cyhalothrin-concentrations at which lowest mortalities were previously observed in the conventional bioassay described above.

For control, 27 larvae were first treated each with either PBO, DEM, or DEF, as above, and then placed in cells containing untreated leaves. Mortality was assessed $56 \mathrm{~h}$ after exposure.

\subsubsection{Sequencing of Domain II of the Voltage-Gated Sodium Channel}

To investigate the presence of the 1014F $k d r$ mutation DNA was extracted [29] from eight larvae alive and eight dead following exposure to $\lambda$-cyhalothrin. Amplification of the fragment encompassing the 1014 codon was done using a nested PCR with the primers described by Haddi and colleagues [24]: TAF3 and TAR1 in the first PCR and the primers TAF4 and TAR2 in the second reaction. To $12.5 \mu \mathrm{L}$ of the $2 \times$ AccuStartII HiFi PCR SuperMix (QuantaBio, Beverly, Massachusetts) containing optimized concentrations of $\mathrm{MgCl}_{2}$ and dNTP mixes, $0.2 \mu \mathrm{M}$ each of the forward and reverse primer was added, followed by $1 \mu \mathrm{L}$ gDNA. $10.5 \mu \mathrm{L}$ of $\mathrm{dH}_{2} \mathrm{O}$ was added to obtain a total volume of $25 \mu \mathrm{L}$. Amplification was carried out using the following conditions: initial denaturation of one cycle at $94{ }^{\circ} \mathrm{C}$ for $3 \mathrm{~min}$; 35 cycles of $94{ }^{\circ} \mathrm{C}$ for $30 \mathrm{~s}$ (denaturation), $60^{\circ} \mathrm{C}$ for $30 \mathrm{~s}$ (annealing), and extension at $72{ }^{\circ} \mathrm{C}$ for $1 \mathrm{~min}$; and one cycle at $72{ }^{\circ} \mathrm{C}$ for $5 \mathrm{~min}$ (final elongation).

Nest 2 product was purified, sequenced on both strands and assembled/edited as described above, and NCBI Blastn used to identify similar sequences in the GenBank. Fifiteen sequences, seven from the larvae alive from $\lambda$-cyhalothrin exposure, and eight from the dead larvae were deposited in the GenBank with accession numbers MK189140-MK189154. 


\subsection{Data Analysis}

The intensity of resistance was estimated by calculating the $\mathrm{LD}_{50}$ for the various insecticides using glm probit analysis as implemented in MASS package of R version 3.5.0 (https:/ / cran.r-project.org/ $\mathrm{bin} /$ windows/base/). All figures were prepared with and the results of synergised and un-synergised tests with $\lambda$-cyhalothrin compared using a two-tailed Chi-Square test of independence using GraphPad Prism 7.02 (GraphPad Inc., La Jolla, CA, USA).

\section{Results}

\subsection{Morphological and Molecular Identification of T. absoluta to Species Level}

The field collected $\mathrm{F}_{0}$ larvae and adults were morphologically identified as T. absoluta (Meyrick 1917) (Lepidoptera: Gelechiidae), based on the following characteristics as explained in previous publications [2,36]: early instars were white/creamy with black heads which changed into greenish from second instar with heads turning to brown/dark brown. The first instar larvae were $<1 \mathrm{~mm}$, and there was gradual increases in length until the fourth instar, which was on average 7-8 $\mathrm{mm}$ long. Second instar larvae were 4-5.5 $\mathrm{mm}$. Pupae were brown in colour and were folded into leaves singly. Adults were about $9-10 \mathrm{~mm}$ long, with filiform antennae, silver-grey scales, and evidence of black spots on anterior wings.

DNA from all the $16 \mathrm{~F}_{0}$ parents produced $\sim 658$ bp characteristic of metazoan cytochrome $\mathrm{c}$ oxidase I [37] (Figure 2). Sequencing of eight PCR products revealed that they were $100 \%$ identical to KX443111 [38], KT452897, KY212128, and KU565719 deposited from previous studies at the NCBI. The 695bp sequences have been deposited in the GenBank: accession numbers MK189155- MK189162.

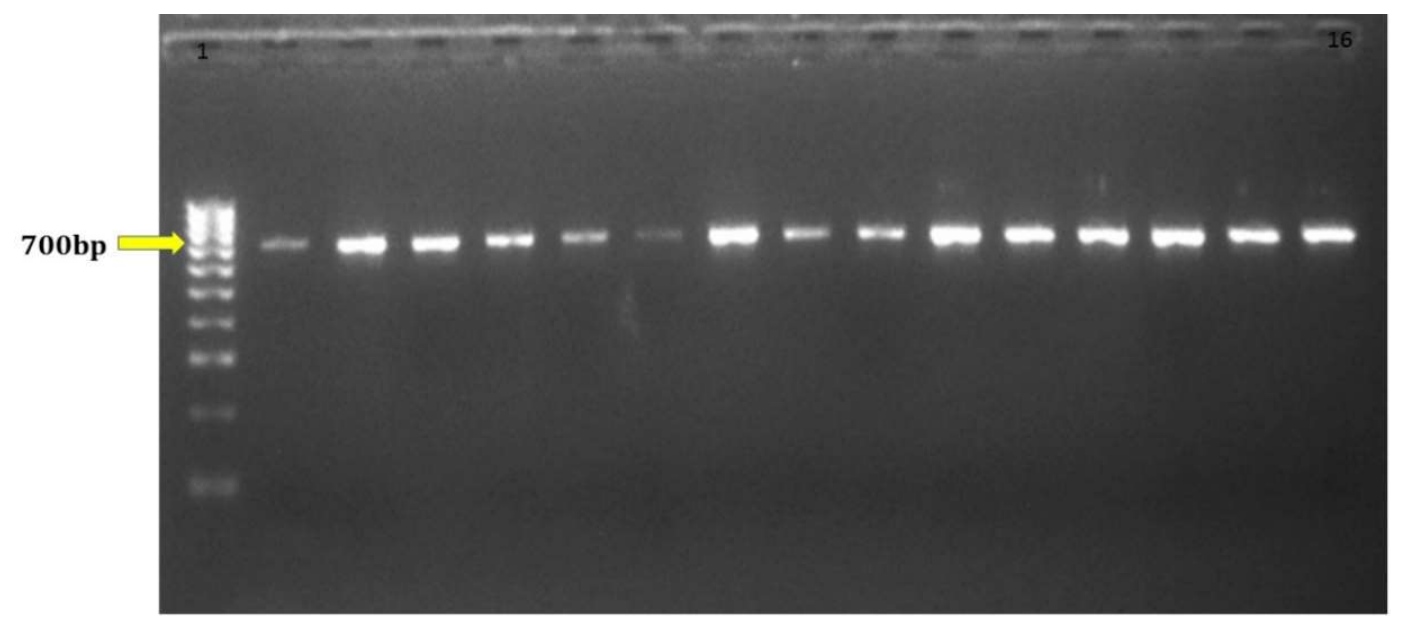

Figure 2. Polymerase chain reaction species identification of T. absoluta species. A characteristic band of 658 bp typical to metazoans is evident in lanes 2-16. Lane 1 represents HypperLadder IV from Bioline ( 1013 bp).

\subsection{Insecticides Resistance Profile of T. absoluta Populations}

The leaf-dip bioassay revealed highest mortality with the type II pyrethroid $\lambda$-cyhalothrin, (average mortality of only $18.52 \% \pm 2.0$ after $56 \mathrm{~h}$ ) (Figure $3 \mathrm{~A}$, Table 1 ) and $\mathrm{LD}_{50}$ of $7461.474 \mathrm{ppm} \pm$ 1213.793 (Table 2). Highest leaf damage ( $15 \%$ of the leaves destroyed) was also observed with this insecticide (Figure 3B, and Table 1), though not significantly different from the other insecticides tested.

In contrast with $\lambda$-cyhalothrin results, approximately $56 \%$ mortalities were recorded respectively, for propoxur and chlorpyrifos-respectively (Figure 3A, Tables 1 and 2). However, the $\mathrm{LD}_{50}$ of propoxur (1023.35 ppm \pm 218.69$)$ was on average ten times higher than obtained with chlorpyrifos-methyl (106.30 ppm \pm 13.09) (Table 1, Table 2) due to the higher mortalities obtained at lower concentrations with the latter. 


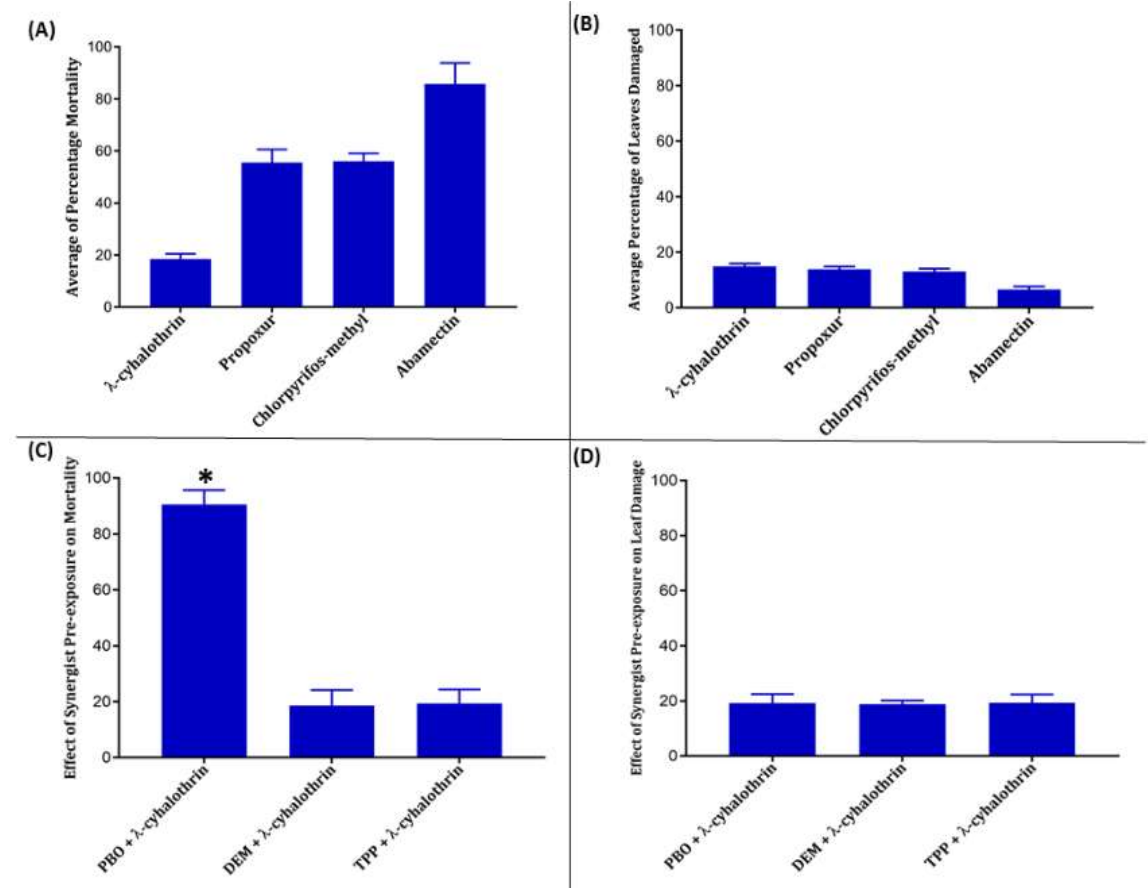

Figure 3. Results of conventional and synergist bioassays with various concentration of insecticides. Average of percentage for six different concentration ranges for each insecticides \pm standard error of mean, for (A) mortalities, (B) leaves damaged, (C) mortalities with pre-exposure to synergists PBO, DEF, and DEM, and (D) leaves damaged from synergist bioassay with PBO. * Significantly different from conventional test with $\lambda$-cyhalothrin only, $\chi^{2}=98.35, p<0.0001$.

Table 1. Susceptibility profiles mortalities) and leaf damage from exposure to various insecticides and synergists.

\begin{tabular}{|c|c|c|c|c|}
\hline $\begin{array}{l}\text { Concentration } \\
(\mathrm{ppm})\end{array}$ & $\begin{array}{c}\text { Population } \\
\text { before Treatment }\end{array}$ & $\begin{array}{c}\text { Population } \\
\text { after Treatment }\end{array}$ & Mortality (\%) & Leaf Damage (\%) \\
\hline \multicolumn{5}{|c|}{ Abamectin } \\
\hline 1000 & 9 & 0 (9 dead) & 100 & 0.22 \\
\hline 166.67 & 9 & 0 (9 dead) & 100 & 2.17 \\
\hline 27.78 & 9 & 0 (9 dead) & 100 & 4.78 \\
\hline 4.630 & 9 & 0 (9 dead $)$ & 100 & 6.00 \\
\hline 0.7716 & 9 & 0 (9 dead $)$ & 100 & 7.22 \\
\hline 0.1286 & 9 & 1 alive (8 dead) & 85.71 & 6.78 \\
\hline 0.0214 & 9 & 4 alive (5 dead) & 42.86 & 12.00 \\
\hline 0.0036 & 9 & 3 alive (6 dead) & 57.14 & 13.44 \\
\hline 0.00 (control) & 9 & 9 alive (0 dead) & 0.00 & 16.61 \\
\hline \multicolumn{5}{|c|}{ Propoxur } \\
\hline 5000 & 9 & 2 alive ( 7 dead) & 77.77 & 5.78 \\
\hline 833.33 & 9 & 3 alive (6 dead) & 66.66 & 8.67 \\
\hline 138.89 & 9 & 4 alive (5 dead) & 55.55 & 9.67 \\
\hline 23.15 & 9 & 4 alive (5 dead) & 55.55 & 14.22 \\
\hline 3.858 & 9 & 5 alive ( 4 dead) & 44.44 & 19.78 \\
\hline 0.643 & 9 & 6 alive ( 3 dead) & 33.33 & 20.22 \\
\hline 0.00 (control) & 9 & 9 alive ( 0 dead) & 0.00 & 25.56 \\
\hline
\end{tabular}


Table 1. Cont.

\begin{tabular}{|c|c|c|c|c|}
\hline $\begin{array}{c}\text { Concentration } \\
(\mathrm{ppm})\end{array}$ & $\begin{array}{c}\text { Population } \\
\text { before Treatment }\end{array}$ & $\begin{array}{c}\text { Population } \\
\text { after Treatment }\end{array}$ & Mortality (\%) & Leaf Damage (\%) \\
\hline \multicolumn{5}{|c|}{$\lambda$-cyhalothrin } \\
\hline 5000 & 9 & 6 alive ( 3 dead) & 33.33 & 7.89 \\
\hline 833.33 & 9 & 7 alive ( 2 dead) & 22.22 & 9.17 \\
\hline 138.89 & 9 & 8 alive ( 1 dead) & 11.11 & 13.33 \\
\hline 23.15 & 9 & 7 alive ( 2 dead) & 22.22 & 16.89 \\
\hline 3.858 & 9 & 8 alive (1 dead) & 11.11 & 19.22 \\
\hline 0.643 & 9 & 8 alive (1dead) & 11.11 & 22.78 \\
\hline 0.00 (control) & 9 & 9 alive ( 0 dead) & 0.00 & 25.56 \\
\hline \multicolumn{5}{|c|}{ Chlorpyrifos-Methyl } \\
\hline 5000 & 9 & 0 alive (9 dead) & 100 & 4.94 \\
\hline 833.33 & 9 & 0 alive (9 dead) & 100 & 8.72 \\
\hline 138.89 & 9 & 4 alive (5 dead) & 50 & 17.78 \\
\hline 23.15 & 9 & 5 alive ( 4 dead) & 37.5 & 17.67 \\
\hline 3.858 & 9 & 5 alive (4 dead) & 37.5 & 16.11 \\
\hline 0.643 & 9 & 8 alive ( 1 dead) & 11.11 & 17.78 \\
\hline 0.00 (control) & 9 & 9 alive ( 0 dead) & 11.11 & 20.44 \\
\hline \multicolumn{5}{|c|}{ Piperonyl Butoxide (PBO) $+\lambda$-cyhalothrin } \\
\hline 138.89 & 9 & 0 alive (9 dead) & 100 & 1 \\
\hline 23.15 & 9 & 0 alive (9 dead) & 100 & 1 \\
\hline 3.858 & 9 & 1 alive (6 dead) & 87.50 & 3 \\
\hline 0.643 & 9 & 2 alive (7 dead) & 75.00 & 5 \\
\hline 0.00 (control) & 27 & 27alive (0 dead) & 0.00 & - \\
\hline \multicolumn{5}{|c|}{ Diethyl Maleate (DEM) $+\lambda$-cyhalothrin } \\
\hline 138.89 & 9 & 7 alive ( 2 dead) & 22.22 & 13.33 \\
\hline 23.15 & 9 & 8 alive (1 dead) & 11.11 & 16.89 \\
\hline 3.858 & 9 & 8 alive ( 1 dead) & 11.11 & 19.22 \\
\hline 0.643 & 9 & 8 alive (1 dead) & 11.11 & 22.75 \\
\hline \multicolumn{5}{|c|}{ Triphenyl Phosphate (TPP) $+\lambda$-cyhalothrin } \\
\hline 138.89 & 9 & 7 alive (2 dead) & 22.22 & 12.66 \\
\hline 23.15 & 9 & 7 alive (2 dead) & 22.22 & 17.47 \\
\hline 3.858 & 9 & 7 alive (2 dead) & 22.22 & 23.10 \\
\hline 0.643 & 9 & 8 alive ( 1 dead) & 11.11 & 20.85 \\
\hline
\end{tabular}

Highest mortality was obtained with abamectin $(85.71 \% \pm 8.1)$ with a very low $\mathrm{LD}_{50}$ of only 0.034 ppm \pm 0.0036 (Figure 3A, Tables 1 and 2). Highest foraging inhibition was also observed with this pesticide with only $\sim 7 \%$ of the leaves damaged at the end of the experiment (Figure 3B, Table 1, and Table 2).

Table 2. Results of probit analyses for insecticides bioassay and leaf damage with various concentrations of insecticides.

\begin{tabular}{|c|c|c|c|c|c|c|}
\hline Insecticides & $n$ & $\begin{array}{c}\text { Leaf Damage } \pm \\
\text { S.E.M. }\end{array}$ & $\begin{array}{c}\text { \% Mortality 土 } \\
\text { S.E.M. }\end{array}$ & $\begin{array}{l}\mathrm{LD}_{50} \\
(\mathrm{ppm})\end{array}$ & $\begin{array}{c}\text { LD }_{50} \\
\text { (S.E.M) }\end{array}$ & $\mathrm{LD}_{50}(\mathrm{FL}$ 95\%) \\
\hline$\lambda$-cyhalothrin & 54 & $14.88 \pm 1.05$ & $18.51 \pm 5.70$ & 7461.47 & 1213.79 & 5082.47-9840.89 \\
\hline Chlorpyrifos-methyl & 54 & $13.06 \pm 1.06$ & $56.01 \pm 3.10$ & 106.30 & 13.09 & 80.75-132.15 \\
\hline Abamectin & 72 & $6.58 \pm 1.10$ & $85.71 \pm 8.10$ & 0.034 & 0.0036 & $0.01-0.09$ \\
\hline
\end{tabular}

Results are an average of percentage (9 larvae) for six different concentration ranges (for abamectin, 8 different concentrations, $n=72$ ) of insecticides. FL = fiducial limit, S.E.M. = standard error of mean for mortalities, leaf damage and $\mathrm{LD}_{50 \mathrm{~s}} \cdot \mathrm{ppm}=$ part per million. $\mathrm{ND}=$ not determined. 


\subsection{Identification of Possible Mechanism of Resistance Using Synergists}

To establish the possible enzyme systems responsible for the pyrethroid resistance synergist assays were conducted for $\lambda$-cyhalothrin with PBO, DEM and TPP. In contrast with the observation from pre-exposure to DEM $\left(\chi^{2}=0.89, p=0.34\right)$ and TPP $\left(\chi^{2}=0.03, p=0.86\right)$ (Table S1), pre-treatment with PBO significantly recovered susceptibility $\left(\chi^{2}=98.35, p<0.0001\right)$ with on average more than four-fold increase in mortalities from $18.5 \%$ to $~ 90 \%$ in synergized bioassay (Figure $3 C$ ). The $\mathrm{LD}_{50}$ plummeted down to only $0.92 \mathrm{ppm} \pm 0.15$, more than 8000 times lower than obtained in the bioassay with $\lambda$-cyhalothrin alone (Table S1). Thus, a synergistic ratio calculated for $\mathrm{PBO}+\lambda$-cyhalothrin was the highest, at 8154.35.

Surprisingly, for all the three synergists tested, no major difference in foraging capability was observed between the synergized tests and conventional treatment with $\lambda$-cyhalothrin (Figure 3D, Table 1).

\subsection{Identification of 1014F kdr Mutation in Domain II of the Voltage-Gated Sodium Channel}

The leucine to phenylalanine $k d r$ mutation commonly reported in resistant species of diverse arthropods [39] was $100 \%$ fixed in seven $\lambda$-cyhalothrin-alive and eight dead larvae from Kadawa. Sequencing unambiguously identified TTT codon in the 1014 position (Figure 4B,C) specific to phenylalanine. The 15 sequences, which were $99 \%$ similar to the NCBI accessions JQ701800 and KY767010, have been deposited in the GenBank.
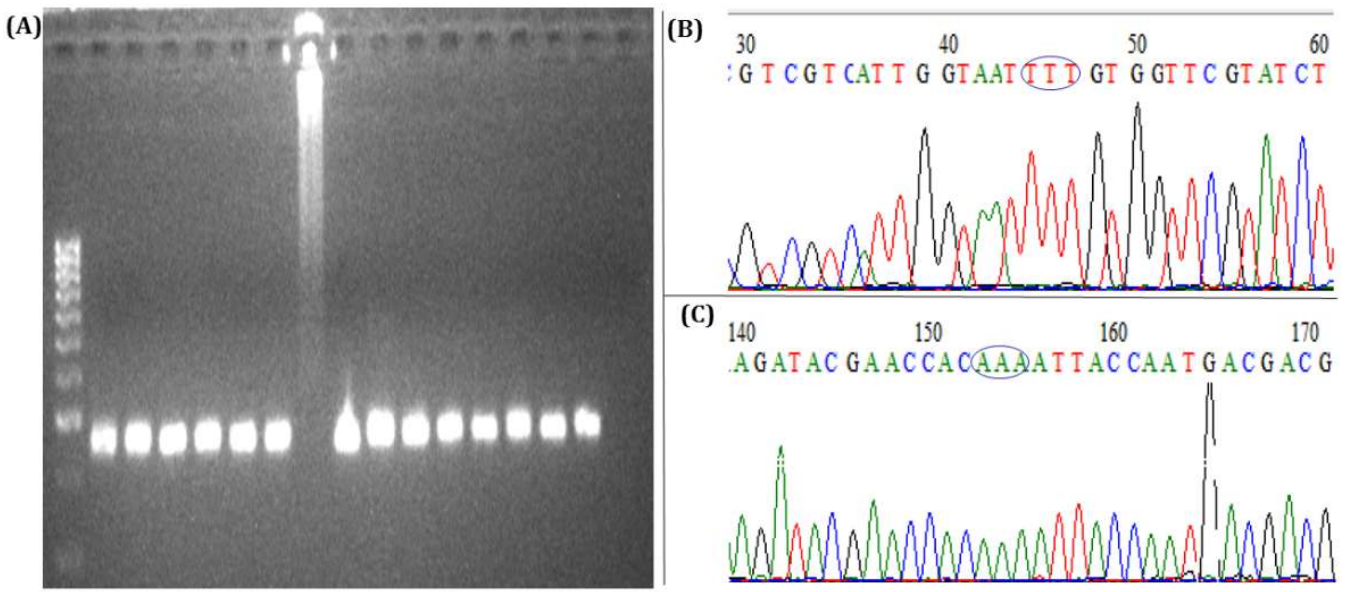

Figure 4. Genotyping of the IIS6 fragment of the voltage-gated sodium channel for the $1014 \mathrm{~F} k d r$ mutation in T. absoluta larvae. (A) Agarose gel of the nest 2 PCR fragment showing a characteristic band of around 270-280 bp; (B) and (C) are chromatogram traces respectively of forward and reverse sequences from a single T. absoluta larvae. The $1014 \mathrm{~F}$ codon is encircled in blue.

\section{Discussion}

Tomato is the second most important vegetable crop in the world, next to potato, and Nigeria is its largest producer in Africa (and ranked 14th largest producer in the world). However, T. absoluta invasion is threatening the sustainability of tomato farming in Nigeria, with millions of Nigerian Naira lost in the recent years. The abrupt expansion and destruction of tomatoes by the leaf miner caught Nigerian farmers and other stakeholders unprepared. Continuous invasion is reported here and there in northern Nigeria, with no clear plans on ground on how to control this pest [17]. In contrast to studies carried out elsewhere in Europe and Americas, except for few reports from Ethiopia, most of the studies done on T. absoluta from sub-Saharan Africa did not describe the insecticides susceptibility status of this pest. For, example, published data from Senegal [11], Burkina Faso [40], Niger [10], Tanzania [12], Angola [41], and Botswana [13] described only ecology and/or bionomics of this pest. 
Pyrethroids being cheap and safest insecticides for mammals are the frontline insecticides for use against agricultural pest. However, the high pyrethroid insensitivity resistance in agricultural pests, as observed in this northern Nigerian populations resulted in a shift to other more effective but expensive pesticides. High resistance to type I pyrethroid permethrin and type II pyrethroids, $\lambda$-cyhalothrin, deltamethrin and $\alpha$-cypermethrin have been previously described for the Brazilian and Iranian populations of T. absoluta [22,24,42]. Our finding of $1014 \mathrm{~F} k d r$ mutation in all the alive and dead larvae from $\lambda$-cyhalothrin exposure was in line with previous findings. This target-site mutation has been described as 100\% fixed in T. absoluta populations from several European countries [24].

In this study, comparable mortalities observed for the organophosphate chlorpyrifos-methyl and the carbamate propoxur, were lower than obtained with $\lambda$-cyhalothrin. Organophosphate and carbamate resistance had been described for T. absoluta populations previously, e.g. for chlorpyrifos and methamidophos in Iranian and Brazilian populations [42,43], and towards methamidophos in the Brazilian populations [43]. Just as established in our study the above studies described multiple resistance to pyrethroids, carbamates and organophosphates in the T. absoluta populations from different parts of the world [42,43]. The lowest mortalities observed towards abamectin was in keeping with a report from Argentine populations with abamectin exhibiting lowest $\mathrm{LD}_{50}$ in three different populations compared to methamidophos and deltamethrin [44]. In a recent study [26] resistance to emamectin benzoate (a derivative of abamectin) has also been shown to exist in populations from Ethiopia.

Synergists PBO, DEM, and TPP have been used by Sequeira and colleagues [45] to synergize abamectin in bioassays with results implicating CYP450s, in comparison to the other two synergists with much lower synergism. This is in agreement with our finding which suggests that CYP450s could be the major drivers of metablic resistance to $\lambda$-cyhalothrin. However, using biochemical assays of enzyme activities another study conducted with Brazilian populations of T. absoluta established greater correlation between pyrethroids resistance and increased levels of both monooxygenases and GSTs [22]. Yet, the presence of the $1014 \mathrm{~F} k d r$ mutation in both alive and dead larvae point to potential metabolic mechanism responsible for the resistance.

\section{Conclusions}

In northern Nigeria, farmers desperate to control T. absoluta often mix and increase the amount and frequency of pesticides they apply. Unfortunately, this unscientific approach could possibly increase selective pressure in this pest populations inducing resistance. The low mortality towards multiple insecticides observed from a population of T. absoluta in a single field in Nigeria is of great concern. However, the highest mortality observed with respect to abamectin suggests its possible potency in the field. But this insecticide as well as diamide insecticides like chloranthraniliprole are very expensive and possibly unaffordable by subsistence farmers in Nigeria. The claim by farmers of better kill with a formulation containing a mixture of emamectin benzoate and teflubenzurone could possibly be due to lower or absence of resistance to the teflubenzurone, which is an insect growth regulator benzoylurea (IRAC Class 15, type 0). Further work need to be conducted with more replicates and more insecticides to establish the resistance profile with higher statistical power. Also, in future, sampling should be carried out at different sites spanning northern Nigeria. This will provide a comprehensive picture of the resistance in the field population of this pest and establish the control failure likelihood.

Supplementary Materials: The following are available online at http:/ /www.mdpi.com/2077-0472/9/1/7/s1, Table S1: Results of synergist bioassay, for mortalities, probit analyses and leaf damage with $\lambda$-cyhalothrin. Figure S1: Results of dose-response bioassay to establish the LD50 for T. absoluta L2 larvae with (A) $\lambda$-cyhalothrin, (B) propoxur, (C) chlorpyrifos-methyl, (D) abamectin, and (E) PBO pre-exposure with $\lambda$-cyhalothrin.

Author Contributions: Conceived and designed by S.S.I., I.B. and M.M.M. collected samples from field and carried out pesticides bioassays. S.S.I. did the molecular analyses with the help of M.M.M., S.S.I. analyzed the data with the help of N.A., I.B. and S.K.H., and wrote the manuscript. All authors read and approved the manuscript. 
Funding: This study was privately sponsored by S.S.I., but apparatus and equipment utilized in the lab and insectaries were from the Wellcome Trust International Training Fellowship in Public Health to S.S.I. (WT201918/Z/16/Z).

Conflicts of Interest: The authors declare no conflict of interest.

\section{References}

1. García, M.F.; Espul, J.C. Bioecology of the tomato moth (Scrobipalpula absoluta) in Mendoza, Argentine Republic. Revista de Investigaciones Agropecuarias 1982, 17, 135-146.

2. European and Mediterranean Plant Protection Organisation. Data sheets on quarantine pests. EPPO Bull. 2005, 35, 434-435. [CrossRef]

3. García, A.U.; Vercher, R.; Llopis, V.N.; Porcuna y Col, J.L.; Marí, F.G. La polilla del tomate, "Tuta absoluta”. Phytoma Espana: La Revista Profesional de Sanidad Vegetal 2007, 194, 16-23.

4. CABI. Invasive Species Compendium. Detailed Coverage of Invasive Species Threatening Livelihoods and the Environment Worldwide. Available online: https://www.cabi.org/ISC/tuta (accessed on 24 October 2018).

5. Tropea, G.G.; Siscaro, G.; Biondi, A.; Zappalà, L. Tuta absoluta, a South American pest of tomato now in the EPPO region: Biology, distribution and damage. EPPO Bull. 2012, 42, 205-210. [CrossRef]

6. Desneux, N.; Luna, M.G.; Guillemaud, T.; Urbaneja, A. The invasive South American tomato pinworm, Tuta absoluta, continues to spread in Afro-Eurasia and beyond: The new threat to tomato world production. J. Pest Sci. 2011, 84, 403-408. [CrossRef]

7. Nayana, B.P.; Kalleshwaraswamy, C.M. Biology and external morphology of invasive tomato leaf miner, Tuta absoluta (Meyrick)(Lepidoptera: Gelechiidae). Pest Manag. Hortic. Ecosyst. 2015, 21, 169-174.

8. Baniameri, V.; Cheraghian, A. The first report and control strategies of Tuta absoluta in Iran. EPPO Bull. 2012, 42, 322-324. [CrossRef]

9. Gashawbeza, A.; Abiy, F. Occurrence of a new leaf mining and fruit boring moth of tomato (Tuta absoluta) in Ethiopia. Field Trip Rep. Ethiop. Inst. Agric. Res. 2013, 11, 2013.

10. Haougui, A.; Adamou, B.; Garba, M.; Oumarou, S.; Gougari, B.; Abou, M.; Kimba, A.; Delmas, P. Confirmation of the presence of Tuta absoluta (Meyrick)(Lepidoptera: Gelechiidae) in Niger (West Africa). J. Sci. Environ. 2016, 5, 4481-4486.

11. Pfeiffer, D.G.; Muniappan, R.; Sall, D.; Diatta, P.; Diongue, A.; Dieng, E.O. First record of Tuta absoluta (Lepidoptera: Gelechiidae) in Senegal. Fla. Entomol. 2013, 96, 661-662. [CrossRef]

12. Maneno, C.; Al-zaidi, S.; Hassan, N.; Julie, A.; Kaaya, E.; Mrogoro, S. First record of tomato leaf miner Tuta absoluta (Meyrick) (Lepidoptera: Gelechiidae) in Tanzania. Agric. Food Secur. 2016, 5, 17.

13. Mutamiswa, R.; Machekano, H.; Nyamukondiwa, C. First report of tomato leaf miner, Tuta absoluta (Meyrick)(Lepidoptera: Gelechiidae), in Botswana. Agric. Food Secur. 2017, 6, 49. [CrossRef]

14. NEPAD: Comprehensive Africa Agriculture Development Programme (CAADP). 2003. Available online: http: / / www.fao.org/nr/water/aquastat/sirte2008/NEPAD-CAADP\%202003.pdf (accessed on 29 July 2018).

15. FAOSTAT: CROPS Statistics for Countries. United Nations, NY. Available online: http://www.fao.org/ faostat/en/\#data/QC (accessed on 5 November 2018).

16. Borisade, O.A.; Kolawole, A.O.; Adebo, G.M.; Uwaidem, Y.I. The tomato leafminer (Tuta absoluta) (Lepidoptera: Gelechiidae) attack in Nigeria: Effect of climate change on over-sighted pest or agro-bioterrorism? J. Agric. Ext. Rural Dev. 2017, 9, 163-171. [CrossRef]

17. Sanda, N.B.; Sunusi, M.; Hamisu, H.; Wudil, B.; Sule, H.; Abdullahi, A. Biological Invasion of Tomato Leaf Miner, Tuta absoluta (Meyrick) in Nigeria: Problems and Management Strategies Optimization: A Review. Asian J. Agric. Hortic. Res. 2018, 1, 1-14. [CrossRef]

18. Punch Newspaper Online. Tomato farmers in Kano lose N2bn to Tuta Absoluta. Punch Newspaper. Available online: https:/ / punchng.com/tomato-farmers-in-kano-lose-n2bn-to-tuta-absoluta/ (accessed on 5 November 2018).

19. Haddi, K.; Berger, M.; Bielza, P.; Rapisarda, C.; Williamson, M.; Moores, G.; Bass, C. Mutation in the ace-1 gene of the tomato leaf miner (Tuta absoluta) associated with organophosphates resistance. J. Appl. Entomol. 2017, 141, 612-619. [CrossRef] 
20. Roditakis, E.; Vasakis, E.; García-Vidal, L.; María del Rosario, M.; Rison, J.L.; Haxaire-Lutun, M.O.; Nauen, R.; Tsagkarakou, A.; Bielza, P. A four-year survey on insecticide resistance and likelihood of chemical control failure for tomato leaf miner Tuta absoluta in the European/Asian region. J. Pest Sci. 2018, 91, 421-435. [CrossRef]

21. Salazar, E.R.; Araya, J.E. Respuesta de la polilla del tomate, Tuta absoluta (Meyrick), a insecticidas en Arica. Agric. Téc. 2001, 61, 429-435. [CrossRef]

22. Silva, W.M.; Berger, M.; Bass, C.; Balbino, V.Q.; Amaral, M.H.; Campos, M.R.; Siqueira, H.A. Status of pyrethroid resistance and mechanisms in Brazilian populations of Tuta absoluta. Pestic. Biochem. Physiol. 2015, 122, 8-14. [CrossRef]

23. Roditakis, E.; Skarmoutsou, C.; Staurakaki, M.; María del Rosario, M.; García-Vidal, L.; Bielza, P.; Haddi, K.; Rapisarda, C.; Rison, J.L.; Bassi, A.; et al. Determination of baseline susceptibility of European populations of Tuta absoluta (Meyrick) to indoxacarb and chlorantraniliprole using a novel dip bioassay method. Pest Manag. Sci. 2013, 69, 217-227. [CrossRef]

24. Haddi, K.; Berger, M.; Bielza, P.; Cifuentes, D.; Field, L.M.; Gorman, K.; Rapisarda, C.; Williamson, M.S.; Bass, C. Identification of mutations associated with pyrethroid resistance in the voltage-gated sodium channel of the tomato leaf miner (Tuta absoluta). Insect Biochem. Mol. Biol. 2012, 42, 506-513. [CrossRef]

25. Ayalew, G. Efficacy of selected insecticides against the South American tomato moth, Tuta absoluta Meyrick (Lepidoptera: Gelechiidae) on tomato in the Central Rift Valley of Ethiopia. Afr. Entomol. 2015, 23, 410-417. [CrossRef]

26. Shiberu, T.; Getu, E. Evaluation of Some Insecticides against Tomato Leaf Miner, Tuta absoluta (Meyrick) (Gelechiidae: Lepidoptera) Under Laboratory and Glasshouse Conditions. Agric. Res. Technol. $2017,7$. [CrossRef]

27. Ranson, H.; Abdallah, H.; Badolo, A.; Guelbeogo, W.M.; Kerah-Hinzoumbe, C.; Yangalbe-Kalnone, E.; Sagnon, N.; Simard, F.; Coetzee, M. Insecticide resistance in Anopheles gambiae: Data from the first year of a multi-country study highlight the extent of the problem. Malar. J. 2009, 8, 299. [CrossRef] [PubMed]

28. Bajonero, J.G.; Parra, J.R.P. Selection and suitability of an artificial diet for Tuta absoluta (Lepidoptera: Gelechiidae) based on physical and chemical characteristics. J. Insect Sci. 2017, 17, 13. [CrossRef] [PubMed]

29. Livak, K.J. Organization and mapping of a sequence on the Drosophila melanogaster $\mathrm{X}$ and $\mathrm{Y}$ chromosomes that is transcribed during spermatogenesis. Genetics 1984, 107, 611-634.

30. Vrijenhoek, R. DNA primers for amplification of mitochondrial cytochrome c oxidase subunit I from diverse metazoan invertebrates. Mol. Mar. Biol. Biotechnol. 1994, 3, 294-299.

31. Tonnang, H.E.; Mohamed, S.F.; Khamis, F.; Ekesi, S. Identification and risk assessment for worldwide invasion and spread of Tuta absoluta with a focus on Sub-Saharan Africa: Implications for phytosanitary measures and management. PLoS ONE 2015, 10, e0135283. [CrossRef] [PubMed]

32. Hall, T.A. BioEdit: A user-friendly biological sequence alignment editor and analysis program for Windows 95/98/NT. Nucleic Acids Symp. Ser. 1999, 41, 95-98.

33. IRAC. Tuta absoluta Susceptibility Test Method \#022. Available online: http://www.irac-online.org/ methods/tuta-absoluta-larvae/ (accessed on 4 March 2017).

34. Nwane, P.; Etang, J.; Chouaïbou, M.; Toto, J.C.; Koffi, A.; Mimpfoundi, R.; Simard, F. Multiple insecticide resistance mechanisms in Anopheles gambiae sl populations from Cameroon, Central Africa. Parasites Vector 2013, 6, 41. [CrossRef] [PubMed]

35. Prasad, K.M.; Raghavendra, K.; Verma, V.; Velamuri, P.S.; Pande, V. Esterases are responsible for malathion resistance in Anopheles stephensi: A proof using biochemical and insecticide inhibition studies. J. Vector Borne Dis. 2017, 54, 226.

36. Sridhar, V.; Chakravarthy, A.; Asokan, R. New record of the invasive South American tomato leaf miner, Tuta absoluta (Meyrick) (Lepidoptera: Gelechiidae) in India. Pest Manag. Hortic. Ecosyst. 2014, 20, 148-154.

37. Hebert, P.D.; Cywinska, A.; Ball, S.L. Biological identifications through DNA barcodes. Proc. R. Soc. Lond. $B$ Biol. Sci. 2003, 270, 313-321. [CrossRef] [PubMed]

38. Sint, D.; Sporleder, M.; Wallinger, C.; Zegarra, O.; Oehm, J.; Dangi, N.; Giri, Y.P.; Kroschel, J.; Traugott, M. A two-dimensional pooling approach towards efficient detection of parasitoid and pathogen DNA at low infestation rates. Methods Ecol. Evol. 2016, 7, 1548-1557. [CrossRef]

39. Davies, T.; Williamson, M. Interactions of pyrethroids with the voltage-gated sodium channel. Bayer CropSci. J. 2009, 62, 159-178. 
40. Son, D.; Bonzi, S.; Somda, I.; Bawin, T.; Boukraa, S.; Verheggen, F.; Francis, F.; Legrève, A.; Schiffers, B. First Record of Tuta absoluta (Meyrick, 1917) (Lepidoptera: Gelechiidae) in Burkina Faso. Afr. Entomol. 2017, 25, 259-263. [CrossRef]

41. Chidege, M.; Abel, J.; Afonso, Z.; Tonini, M.; Fernandez, B. Tomato Leaf Miner, Tuta absoluta (Meyrick) (Lepidoptera: Gelechiidae) Detected in Namibe Province Angola. J. Appl. Life Sci. Int. 2017, 12, 1-5. [CrossRef]

42. Zibaee, I.; Mahmood, K.; Esmaeily, M.; Bandani, A.; Kristensen, M. Organophosphate and pyrethroid resistances in the tomato leaf miner Tuta absoluta (Lepidoptera: Gelechiidae) from Iran. J. Appl. Entomol. 2018, 142, 181-191. [CrossRef]

43. Siqueira, H.A.; Guedes, R.N.; Picanço, M.C. Insecticide resistance in populations of Tuta absoluta (Lepidoptera: Gelechiidae). Agric. For. Entomol. 2000, 2, 147-153. [CrossRef]

44. Lietti, M.M.; Botto, E.; Alzogaray, R.A. Insecticide resistance in Argentine populations of Tuta absoluta (Meyrick) (Lepidoptera: Gelechiidae). Néotrop. Entomol. 2005, 34, 113-119. [CrossRef]

45. Siqueira, H.A.; Guedes, R.; Fragoso, D.B.; Magalhaes, L. Abamectin resistance and synergism in Brazilian populations of Tuta absoluta (Meyrick) (Lepidoptera: Gelechiidae). Int. J. Pest Manag. 2001, 47, 247-251. [CrossRef]

(C) 2019 by the authors. Licensee MDPI, Basel, Switzerland. This article is an open access article distributed under the terms and conditions of the Creative Commons Attribution (CC BY) license (http:/ / creativecommons.org/licenses/by/4.0/). 